\title{
Optimization of Copper Removal by Photovoltaic Electrocoagulation from Aqueous Solution Using Response Surface Methodology Towards Sustainable Development
}

\author{
Hoa Nguyen Thanh ${ }^{1 *}$, Lien Nguyen', Phuong Dinh Thi Lan' \\ 1 Faculty of Environment, Thuyloi University, 175 Tay Son, Dong Da district, Ha Noi, Viet Nam \\ * Corresponding autor's e-mail:nthoa@tlu.edu.vn
}

\begin{abstract}
This research aims at illustrating the optimal functions of removing copper ions in aqueous solution by means of the electrocoagulation process in which portable solar power generators are used as renewable energy. A solar photovoltaic cell (PV), producing approximately $48 \mathrm{~A}$ current intensity for $4-7 \mathrm{~h}$ per day, was sufficient to charge the lithium batteries completely during the day. This system was connected directly to the electrocoagulation tank. The Box-Behnken design (BBD) was applied to evaluate three effects of process factors: current density, the dose of electrolyte $(\mathrm{NaCl})$, and application time. The results showed that an optimal efficiency of $99.01 \% \mathrm{Cu}$ removal plus an energy savings of $1.039 \mathrm{kWh} / \mathrm{m}^{3}$ were obtained at a current density of $4 \mathrm{~A} / \mathrm{m}^{2}$, the dosage of $\mathrm{NaCl}$ (electrolyte) of $1.87 \mathrm{~g} / \mathrm{L}$, and electrolysis time of $10 \mathrm{~min}$. The chemical components of the sludge produced under these optimized conditions were determined by means of EDX. It was illustrated that the copper ions were the main elements of sludge, and nonhazardous compounds were contained. The PV-lithium battery system is considered to be an efficient alternative energy source toward sustainable development.
\end{abstract}

Keywords: photovoltaics; electrocoagulation; copper; Box-Behnken design; energy consumption; lithium battery; sustainable development

\section{INTRODUCTION}

Copper is considered one of the most toxic heavy metals for living cells, and it is one of the more widespread heavy metal pollutants in the environment [Kamaraj et al., 2013]. The elevated levels of copper ions occur from industrial sources, such as electroplating, paints and dyes, petroleum refining, and metal production The application of agricultural chemical, fertilisers, wood burning or waste incinerators, as well as sewage treatment processes commonly contributes to the generation of copper ions and their release to the environment [Shrivastava, 2009]. Besides, the lower concentration of copper is discharged naturally from the Earth's crust. The surface water can become polluted by acids, bases, and heavy metals, such as lead and copper that originate from various industrial processes, and they can have a severe effect on the people's health. Copper is a fundamental element demanded health and wellbeing in humans as it is included in a difference of proteins and metalloenzymes, which accomplish crucial metabolic functions for tissue and bone development. However, the excessive $\mathrm{Cu}^{2+}$ utilisation has an impact on the liver, and subsequent vomiting causes headache, nausea, respiratory problems, abdominal pain and, lastly, gastrointestinal bleeding [Simsek et al., 2013; El-Ashtoukhy and Abdel-Aziz, 2013; Parlak and Arar, 2018]. Degradation of copper ions from water can be achieved by using the chemical or physicochemical methods [Gunatilake, 2015] such as adsorption [Hossain, 2012; Balintova et al., 2012; Demcak et al., 2017] ion-exchange [Edebali and Pehlivan, 2016], photocatalysis [Kanakaraju et al., 2017], or electrochemical processes [Kamaraj et al., 2013; Dermentzis et al., 2011]. Compared to this research, electrocoagulation compares well as an alternative to the conventional wastewater 
removal techniques [Al-Saydeh et al., 2017]. Electro-coagulation is the electrochemical generation of destabilisation operators that induce the charge of neutrality level for removing contaminants and has already been utilized for treating water and wastewater [Vasudevan, 2012]. The Al and $\mathrm{Fe}$ materials are most regularly applied as an electrode due to the following advantages: availability, low price, and non-toxicity. The iron and aluminium ions generated from these electrodes can withstand hydrolysis at the surface of an anode to perform a sequence of activated intermediates that can diminish the delicately dispersed molecules appearing in the wastewater. Then, the flocs can be formed from aggregating of destabilised particles [Vasudevan et al., 2009]. When aluminium is applied as an anode, the chemical reactions which are given below occur:

At the cathode:

$$
2 \mathrm{H}_{2} \mathrm{O}+2 \mathrm{e}^{-} \rightarrow \mathrm{H}_{2(\mathrm{~g})}+2 \mathrm{OH}^{-}
$$

At the anode:

$$
\mathrm{Al} \rightarrow \mathrm{Al}^{3+}+3 \mathrm{e}^{-}
$$

In solution,

$$
\mathrm{Al}^{3+}{ }_{(\text {aq }}+3 \mathrm{H}_{2} \mathrm{O} \rightarrow \mathrm{Al}(\mathrm{OH})_{3}+3 \mathrm{H}^{+} \text {(aq) }
$$

However, the major disadvantage of EC is its high electricity consumption, which also constitutes a critical environmental issue and has economic impact. Thus, the application of traditional electrical energy to power an electrocoagulation reactor is the primary barrier to wider utilization in developing countries where the electrical grids are less reliable [Cucchiella et al., 2016; Ganiyu et al., 2019].

Photovoltaic panels (PV), have been used as a reliable, available and unlimited renewable energy source to replace the traditional electricity [Montiel et al., 2018]. The application of battery energy storage (capacitance) has been used to provide the energy produced on a bright sunny day, which is stored for use on a raining day or at night. Furthermore, using photovoltaic battery systems solves the issue of tremendous output power frequently encountered in PV arrays [Ganiyu et al., 2019]. As such, an electrocoagulation system powered by a PV-battery cell can operate full time, regardless of the solar intensity [Ganiyu et al., 2019]. Several studies have illustrated the feasibility of PV energy in the treatment of contaminants found in the water and wastewater [Ganiyu et al., 2019; Khemila et al., 2018;
Hussin et al., 2017; Millán et al., 2018; Nawarkar and Salkar, 2019]. Nevertheless, these studies paid attention to the availability of applying a PV energy source for degrading the organic pollutants from the water and wastewater. Thus, the PV applications must further be investigated in terms of heavy metals removal [Hussin et al., 2017].

The efficiency of the EC process influences many elements such as $\mathrm{pH}$, applied electric current, the dosage of electrolyte, and the time reaction [Ölmez, 2009]. In traditional multi-factor experiments, optimization is usually realized by changing a factor while keeping other components fixed at a particular arrangement of conditions. Recently, Box - Behnken Design (BBD) in a response surface method (RSM) has become a valuable design tool for the optimisation of processes. BBD provides far-reaching consequence and detailed info indeed in a smaller number of experiments and can display the interactive effects of experimental components on all responses [Kabuk et al., 2014; Shokri et al.,2017].

Accordingly, this research was undertaken for removing copper ion $\left(\mathrm{Cu}^{2+}\right)$-contaminated water by a photovoltaic-electrocoagulation (PV-EC) process using aluminium electrodes to optimise the degradation capabilities of copper and the system energy consumption. Additionally, the optimal process applying BBD tool of Design-Expert Software (11 trial, Stat-Ease Inc. Minnepolis) (DX11) was realized by three parameters, namely current density, experimental duration, and concentration of the of support electrolysis. The trial and model-predicted information obtained the best settings for the PV-EC process design with the least energy consumption and highest removal efficiency of $\mathrm{Cu}^{2+}$. The sludge was produced at the optimum operating parameter of the EC process, examined by means of EDX.

\section{MATERIALS AND METHODS}

\section{Chemicals}

Copper sulfate $\mathrm{CuSO}_{4} \cdot 5 \mathrm{H}_{2} \mathrm{O}$ (Merck, Germany), sodium hydroxide ( $\mathrm{NaOH}$, Merck), sulfuric acid ( $\mathrm{HCl}$, Merck), sodium chloride $(\mathrm{NaCl}$, Merck) of analytical reagent were employed to prepare the aqueous solutions for the experiments. The $\mathrm{pH}$ of the solutions was changed by adding $0.1 \mathrm{M} \mathrm{HCl}$ or $0.1 \mathrm{M} \mathrm{NaOH}$. All solutions were made with double distilled water at room temperature $\left(25^{\circ} \mathrm{C} \pm 1\right)$ every day. 


\section{PV-lithium battery system and electrocoagulation process setup}

The PV-EC experiments were conducted using two PV panels made of polycrystalline silicon (ArmSolar, Singapore) with a size of $659 \times 387 \times 25 \mathrm{~mm}$, connected in arrays with a total power supply of $70 \mathrm{~W}$. The portable solar generator, including MPPT (Solar V, Vietnam) converted the electricity directly from the solar panels to the lithium battery (Solar V, 12 V/240 Ah each) (Fig. 1). The portable solar generator was regulated by the current supply to the electrocoagulation tank.

A lab-scale electrocoagulation reactor constituted a $1 \mathrm{~L}$ glass cell that was $10 \mathrm{~mm}$ (width) $\times$ $12 \mathrm{~mm}$ (length) $\times 15 \mathrm{~mm}$ (height) and was set up with two parallel monopolar electrodes with a 2-cm interelectrode distance. The anode and cathode of the electrocoagulation reactor were made of Al with dimensions of $2 \times 7 \times 17 \mathrm{~mm}$. Before each test, the aluminium electrodes were prepared as follows: washing with $0.1 \mathrm{M} \mathrm{HCl}$ to remove surface matter and then rewashing withthe distilled water, drying in the oven and weighing. Copper sulfate, $\mathrm{CuSO}_{4} \cdot 5 \mathrm{H}_{2} \mathrm{O}$, (Merck, Germany), was used with distilled water to make a concentration of $50 \mathrm{mg} / \mathrm{L}$ copper. The $\mathrm{pH}$ of the aqueous solution, analyzed by means of a digital pH-meter (Eutech, Singapore), was adjusted up to 5 by $0.1 \mathrm{M} \mathrm{HCl}$ (Xichlong, China) and $0.1 \mathrm{M}$ $\mathrm{NaOH}$ (Xichlong, China).

The PV-EC process was carried out in aqueous solutions containing $50 \mathrm{mg} / \mathrm{L} \mathrm{Cu}^{2+}$ and concentrations of $\mathrm{NaCl}$ from $1 \mathrm{~g} / \mathrm{L}$ to $3 \mathrm{~g} / \mathrm{L}$, in batch mode. For retention times ranging from 10 to 30 minutes, different current densities varying between $1-4 \mathrm{~A} / \mathrm{m}^{2}$ were changed with a rheostat (PHCAN-B009PINJNS, China). Finally, the sample was filtered; in order to determine this filtrate, the electrodes were dried and reweighed. A quantity of sludge formed from the PV-EC system was analyzed by filtering, using a $0.45 \mu \mathrm{m}$ filter paper (Whatman, UK) then drying at $103-105^{\circ} \mathrm{C}$ in an oven (Blinder, UK).

\section{Experiment design}

The optimization of the experimental setting for the degradation of copper by PV-EC process was performed by applying the Box - Behnken design (BBD). Three main factors were chosen to estimate the impact on experimental parameters for the copper degradation and energy consumption: current density, $\mathrm{A}\left(\mathrm{A} / \mathrm{m}^{2}\right),\left(\mathrm{X}_{1}\right)$, initial the dosage of $\mathrm{NaCl}(\mathrm{g} / \mathrm{L})\left(\mathrm{X}_{2}\right)$, and electrolysis time $(\min )\left(\mathrm{X}_{3}\right)$, as shown in Table 1 .

\section{Analytical methods}

The copper was determined with the atomic absorption spectroscopy method (AAS) (SavantAA $\Sigma$, GBC, Australia) according to the EPA 7000B standard. The sludge after the electrocoagulation process was analyzed with an X-ray diffractometer (JSX-1000S, JEOL, Japan).

The copper removal efficiency $(\% \mathrm{Cu})$ was calculated as:

$$
\% C u=\left(1-\frac{H}{H_{0}}\right) \times 100 \%,
$$

where: $H_{0}$ and $\mathrm{H}$ are the initial and final copper concentrations.

Energy consumption was calculated with the following equation:

$$
W\left(W h / m^{3}\right)=\frac{U x I x t}{V}
$$

where: $W$ is the energy consumption $\left(\mathrm{Wh} / \mathrm{m}^{3}\right)$, $U$ is the applied voltage $(\mathrm{V})$,

$I$ is the current (A), $\mathrm{t}$ is time (h), and $V$ is the volume of the sample $\left(\mathrm{m}^{3}\right)$.

\section{Data analysis}

For the calculations of the PV-EC operation setting, the response variable was fitted by a second-order model in the form of the quadratic polynomial equation, which is as follows:

$$
\begin{aligned}
Y= & b_{0}+\sum_{i=0}^{k} b_{i} X_{i}+\sum_{i=0}^{k} b_{i i} X_{i}^{2} \\
& +\sum_{i=0}^{k} \sum_{j=0}^{k} b_{i} b_{j} X_{i} X_{j}
\end{aligned}
$$

where: $Y$ is the predicted response (Copper removal efficiency, $\%$ and energy consumption, $\mathrm{kWh} / \mathrm{m}^{3}$ ) applied as the dependent variable;

$X_{i}(i=1,2$ and 3$)$ are the independent variablefactors, and $b_{0}, b_{i}(i=1,2$ and 3$)$, $b_{i j}$ and $b_{i j}(i=1,2$ and $3 ; j=1,2$ and 3 ) are the model coefficients, respectively. 


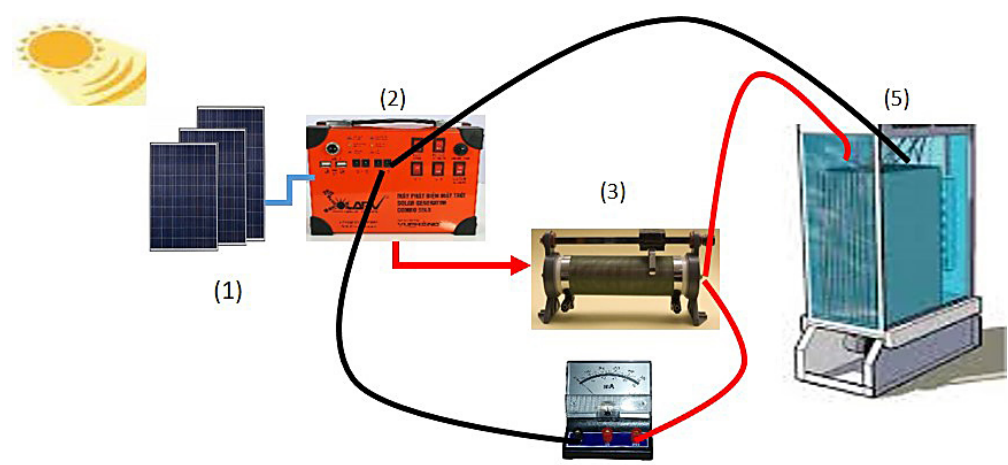

(4)

Figure 1. Diagram of the experimental setup: 1 - solar panel, 2 - solar generator, 3 -rheostat, 4 - ammeter, 5 - electrocoagulation reactor

Table 1. Coded and actual levels of the variables of the design of experiments for the overall electro-coagulation optimization

\begin{tabular}{|l|c|c|c|c|}
\hline \multirow{2}{*}{ Factor } & \multirow{2}{*}{ Variables } & \multicolumn{3}{|c|}{ Coded levels of variables } \\
\cline { 3 - 5 } & & -1 & 0 & 1 \\
\hline Current density & $\mathrm{A} / \mathrm{m}^{2}$ & 1 & 2.5 & 4 \\
\hline NaCl concentration & $\mathrm{g} / \mathrm{L}$ & 1 & 2 & 3 \\
\hline Electrolysis time & $\mathrm{Min}$ & 10 & 20 & 30 \\
\hline
\end{tabular}

Experimental output was analysed by the DX11 (trial) program with ANOVA to show the interplay between the process values and the responding variable. 2-D contour plots and 3-D contours of the response surfaces were performed in the same program.

\section{RESULTS AND DISCUSSION}

\section{Response analysis and explanation by BBD method}

The 3-factorial experiments were carried out under the BBD with the DX11 software using the predicted and experimental data of the responses (copper removal $\left(\mathrm{Y}_{1}\right)$ and energy consumption $\left(\mathrm{Y}_{2}\right)$ ), which are presented in Table 2. The response functions with the fix coefficients for copper and energy consumption are performed with equations (7) and (8)

$\mathrm{Y}_{1}($ copper removal, \%) $=58.94333+$ $9.13583 \mathrm{X}_{1}+5.20042 \mathrm{X}_{2}+0.851750 \mathrm{X}_{3}-$ $1.25167 \mathrm{X}_{1} \mathrm{X}_{2}-0.13 \mathrm{X}_{1} \mathrm{X}_{3}-0.009763 \mathrm{X}_{3}^{2}$

$\mathrm{Y}_{2}$ (energy consumption, $\mathrm{kWh} / \mathrm{m}^{3}$ ) $=1.87181-2.81528 \mathrm{X}_{1}-5.58833 \mathrm{X}_{2}-$ $1.25167 \mathrm{X}_{1} \mathrm{X}_{2}-0.121667 \mathrm{X}_{1}^{2}+0.151125$ $\mathrm{X}_{2}^{2}-0.009763 \mathrm{X}_{3}^{2}$
The response function forecasts suited the experimental data completely (Table 3$)\left(\mathrm{R}^{2}=99.77 \%\right.$ for $\mathrm{Y}_{1}$ and $\mathrm{R}^{2}=99.66 \%$ for $\mathrm{Y}_{2}$ ). Both of the correlation coefficient values $\left(\mathrm{R}^{2}\right)$ achieved in the current research for these dependent variables were higher than 0.80 , pointing out that the regression modellings justified the reaction correctly. Thus, the response surface model promoted in this research for the prediction of removing copper feasibility and energy consumption was determined acceptably [Ölmez, 2009].

The quadratic regression technique is appropriate, being apparent from the F-test with a shallow probability value (Prob $>$ F). Table 3 resulted in ANOVA analysis considering the significance of factors in PV-EC experiment through equation (7) and (8). Because the p-values of each coefficient are less than 0.05 , it shows that indicate model terms are significant. From Table 3, the $\mathrm{Y}_{1}$ model terms $\mathrm{X}_{1}, \mathrm{X}_{2}, \mathrm{X}_{3}, \mathrm{X}_{1} \mathrm{X}_{2}, \mathrm{X}_{2} \mathrm{X}_{3}$, and $\mathrm{X}_{3}^{2}$, as well as $\mathrm{Y}_{2}$ model calls $\mathrm{X}_{1}, \mathrm{X}_{1}^{2}, \mathrm{X}_{2}^{2}, \mathrm{X}_{3}^{2}$ had a significance of impact on the energy consumption because the p-value is less than 0.05 .

The surface response of the second-degree polynomial model with a variable was maintained at an average value and the two remained ones changing in an experimental range are described in Figures 2-4. In Figure 2, the response surface was shown as a function of current density and the initial $\mathrm{NaCl}$ concentration as electrolyte concentration within the operation time kept at 20 min. The average value, $98.6 \% \mathrm{Cu}^{2+}$ removal, was obtained at 20 min application time while the current density was $4 \mathrm{~A} / \mathrm{m}^{2}$ and the electrolyte $(\mathrm{NaCl})$ concentration was $3 \mathrm{~g} / \mathrm{L}$. Similarly, Figure 3 investigates the response under the dosage of variables such as current density and electrolyte 
Table 2. Independent variables and response from Box-behken Design

\begin{tabular}{|c|c|c|c|c|c|c|c|}
\hline \multirow{2}{*}{ Run } & \multicolumn{3}{|c|}{ Independent variables } & \multicolumn{4}{c|}{ Response $(\mathrm{Y})$} \\
\cline { 2 - 8 } & $\mathrm{X}_{1}\left(\mathrm{~A} / \mathrm{m}^{2}\right)$ & $\mathrm{X}_{2}(\mathrm{~g} / \mathrm{L})$ & $\mathrm{X}_{3}(\mathrm{~min})$ & \multicolumn{2}{c|}{ Experimental } & \multicolumn{2}{c|}{ Predicted } \\
\cline { 2 - 8 } & Current density & Dose of $\mathrm{NaCl}$ & Time & $\begin{array}{c}\text { Copper } \\
\text { removal } \\
(\%)\end{array}$ & $\begin{array}{c}\text { Energy } \\
\text { consumption } \\
\left(\mathrm{kWh} / \mathrm{m}^{3}\right)\end{array}$ & $\begin{array}{c}\text { Copper } \\
\text { removal } \\
(\%)\end{array}$ & $\begin{array}{c}\text { Energy } \\
\text { consumption } \\
\left(\mathrm{kWh} / \mathrm{m}^{3}\right)\end{array}$ \\
\hline 1 & 4 & 2 & 10 & 96.8 & 1.07 & 96.81 & 1.11 \\
\hline 2 & 2.5 & 3 & 30 & 95.3 & 1.96 & 95.40 & 2.13 \\
\hline 3 & 1 & 2 & 10 & 82.7 & 0.64 & 82.66 & 0.6862 \\
\hline 4 & 2.5 & 2 & 20 & 92.8 & 1.07 & 92.30 & 1.12 \\
\hline 5 & 4 & 3 & 20 & 98.2 & 5.59 & 98.06 & 5.46 \\
\hline 6 & 2.5 & 2 & 20 & 91.7 & 1.25 & 92.30 & 1.12 \\
\hline 7 & 4 & 2 & 30 & 95.5 & 1.07 & 95.54 & 1.02 \\
\hline 8 & 2.5 & 3 & 10 & 92.7 & 2.3 & 92.83 & 2.39 \\
\hline 9 & 1 & 1 & 20 & 82.4 & 2.74 & 82.54 & 2.87 \\
\hline 10 & 1 & 2 & 30 & 89.2 & 0.64 & 89.19 & 0.5987 \\
\hline 11 & 2.5 & 1 & 10 & 87.6 & 0.23 & 87.50 & 0.0550 \\
\hline 12 & 2.5 & 1 & 30 & 90.3 & 0.22 & 90.18 & 0.1325 \\
\hline 13 & 2.5 & 2 & 20 & 92.4 & 1.04 & 92.30 & 1.12 \\
\hline 14 & 1 & 3 & 20 & 91.7 & 5.75 & 91.61 & 5.62 \\
\hline 15 & 4 & 1 & 20 & 96.5 & 3.74 & 96.59 & 3.87 \\
\hline
\end{tabular}

Table 3. ANOVA outputs for copper reduction and energy consumption by PV-EC process

\begin{tabular}{|c|c|c|c|c|c|c|c|c|c|c|}
\hline \multirow{2}{*}{ Source } & \multicolumn{5}{|c|}{ Copper removal (\%) } & \multicolumn{5}{|c|}{ Energy consumption $\left(\mathrm{Wh} / \mathrm{m}^{3}\right)$} \\
\hline & DF & ss & MS & F-value & Prob $>F$ & DF & SS & MS & F-value & Prob $>F$ \\
\hline Model & 9 & 313.20 & 34.80 & 243.78 & $\begin{array}{c}<0.0001 \\
\text { significant }\end{array}$ & 9 & 43.55 & 4.84 & 162.99 & $\begin{array}{c}<0.0001 \\
\text { significant }\end{array}$ \\
\hline $\begin{array}{l}\mathrm{X}_{1} \text {-Current } \\
\text { density }\end{array}$ & 1 & 211.05 & 211.05 & 1478.40 & $<0.0001$ & 1 & 0.4186 & 0.4186 & 14.10 & 0.0132 \\
\hline $\begin{array}{l}\mathrm{X}_{2} \text { - Dose of } \\
\mathrm{NaCL}\end{array}$ & 1 & 55.18 & 55.18 & 386.52 & $<0.0001$ & 1 & 9.12 & 9.12 & 307.11 & $<0.0001$ \\
\hline $\mathrm{X}_{3}$-Time & 1 & 13.78 & 13.78 & 96.54 & 0.0002 & 1 & 0.0153 & 0.0153 & 0.5158 & 0.5048 \\
\hline$x_{1} x_{2}$ & 1 & 14.10 & 14.10 & 98.77 & 0.0002 & 1 & 0.2652 & 0.2652 & 8.93 & 0.0305 \\
\hline$x_{1} x_{3}$ & 1 & 15.21 & 15.21 & 106.55 & 0.0001 & 1 & 0.0000 & 0.0000 & 0.0000 & 1.0000 \\
\hline $\mathrm{x}_{2} \mathrm{X}_{3}$ & 1 & 0.0025 & 0.0025 & 0.0172 & 0.9008 & 1 & 0.0272 & 0.0272 & 0.7606 & 0.4230 \\
\hline $\mathrm{X}_{1}^{2}$ & 1 & 0.2767 & 0.2767 & 1.94 & 0.2226 & 1 & 8.20 & 8.20 & 276.14 & $<0.0001$ \\
\hline$X_{2}^{2}$ & 1 & 0.0845 & 0.0845 & 0.5917 & 0.4765 & 1 & 12.13 & 12.13 & 408.62 & $<0.0001$ \\
\hline $\mathrm{X}_{3}^{2}$ & 1 & 3.52 & 3.52 & 24.65 & 0.0042 & 1 & 11.37 & 11.37 & 383.10 & $<0.0001$ \\
\hline Residual & 5 & 0.7138 & 0.1428 & & & 5 & 0.1484 & 0.0297 & & \\
\hline Lack of fit & 3 & 0.0938 & 0.0313 & 0.1008 & 0.9524 & 3 & 0.1226 & 0.0409 & 3.17 & $\begin{array}{l}0.2491 \text { not } \\
\text { significant }\end{array}$ \\
\hline $\mathrm{R}^{2}$ & & 0.9977 & & & & & 0.9966 & & & \\
\hline $\mathrm{R}^{2}$ adjusted & & 0.9936 & & & & & 0.9905 & & & \\
\hline $\mathrm{R}^{2}$ predicted & & 0.9908 & & & & & 0.9538 & & & \\
\hline
\end{tabular}

concentration. It demonstrated a significant increase in the energy consumption $\left(\mathrm{Wh} / \mathrm{m}^{3}\right)$ when the current density was increased. The electrolyte concentration was shown not to have much impact on energy saving.

In order to research the influence of electrolyte dosage and the operation time on copper reduction, the experiments were performed with the dose of electrolyte $(\mathrm{NaCl})$ range were from $1-3 \mathrm{~g} / \mathrm{L}$ in other contact times at a current density of $2.5 \mathrm{~A} / \mathrm{m}^{2}$. The results are discussed in Figure 4 showing that the copper degradation efficiency increased along with the application time at all investigated doses of electrolyte. The maximum copper concentration was removed at $30 \mathrm{~min}$ and with an electrolyte concentration of $3 \mathrm{~g} / \mathrm{L}$. Thus, 


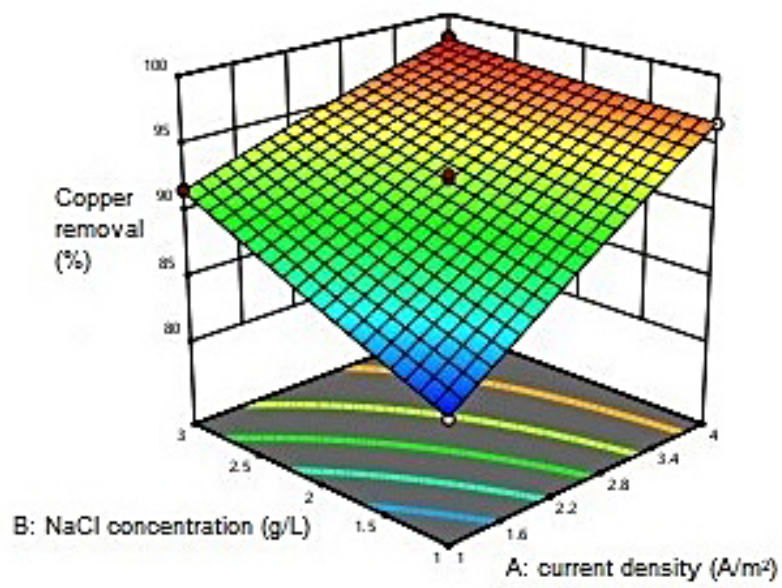

Figure 2. The effect of current density and electrolyte $(\mathrm{NaCl})$ concentration on copper removal (application time: $20 \mathrm{~min}$ )

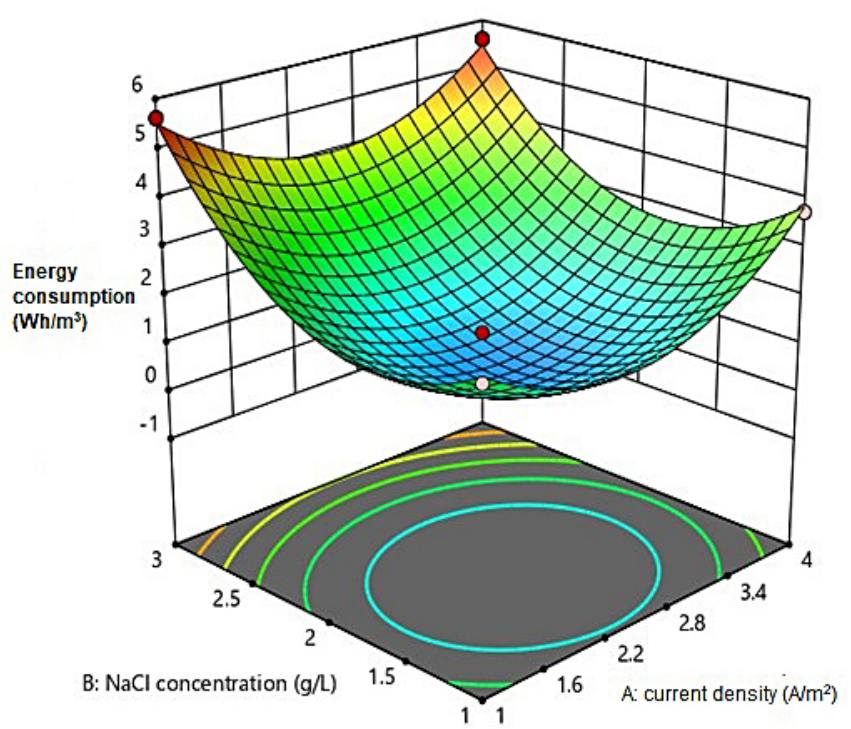

Figure 3. The impact on current density and electrolyte concentration on energy consumption (application time: $20 \mathrm{~min}$ )

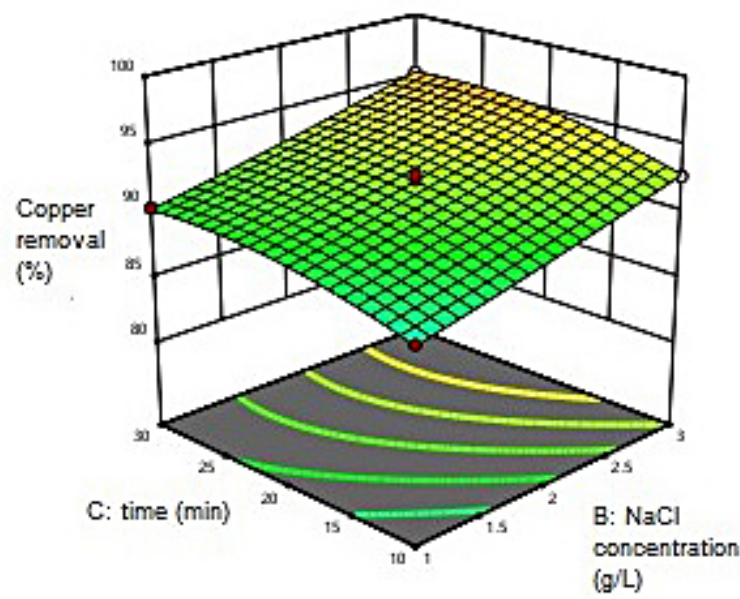

Figure 4. The effect of the dosage of $\mathrm{NaCl}$ and application time on copper removal (the current density $2.5 \mathrm{~A} / \mathrm{m}^{2}$ ) 
it can be showed that the operation time has a more considerable influence on the $\mathrm{Cu}^{2+}$ removal efficiency than the dose of electrolyte.

\section{Optimization of the PV-EC process for copper removal}

The primary goal of optimization is to show the optimal values of the variables for copper reduction and energy saving with PV-EC from the variety achieved by applying experimental input. The aim desired for the response (the effect of removing copper) was selected to be a maximum target value with the lowest amount of energy consumption, which was affected by the applied voltage, the dose of electrolyte, and operation time. The optimization of the PV-EC process for the copper reduction is shown in Table 4. The optimal condition of the experimental variables was current density at $4 \mathrm{~A} / \mathrm{m}^{2}, \mathrm{NaCl}$ concentration $=1.87 \mathrm{mg} / \mathrm{L}$, and time $=10 \mathrm{~min}$, while the predicted responses were $96.72 \%$ and $1.03 \mathrm{kWh} /$ $\mathrm{m}^{3}$ for copper reduction and energy consumption, respectively. The desirability function value was determined to be 0.886 under the optimum conditions. As shown in Table 4, PV-EC is considered a suitable technology for optimum degradation of $\mathrm{Cu}^{2+}$ ions under a reasonable operating setting.

An additional experiment was illustrated under the optimal experimental setting based on the results showed in Table 5 to confirm the model accuracy and potency of the optimization procedure. The experimental results have approximately the same value as the predicted results under the optimum conditions. These results verify that BBD is a powerful tool for optimizing the operational requirements of EC for copper removal.

\section{Sludge from the EC process}

The EDX spectra show the elemental compositions of the sludge generated by the electrocoagulation process with $\mathrm{Al}$ electrodes, given in Figure 5. Copper ions are shown to be the primary component of the sludge at $15.85 \%$. Other elements, including carbon, chlorine, oxygen, and sulfur, which could appear with the presence of organic and inorganic matter $\left(\mathrm{Cl}^{-}\right)$, and sodium, were shown with the weight percentage of each element in Table 6 . Thus, the sludge formed by the PV-EC process in this research is also nonhazardous, which makes its management and disposal more convenient and less expensive.

\section{Prospective application of solar energy- based electrocoagulation system}

Alternatively, the coupling of these two technologies, electrocoagulation and PV with battery storage can provide a useful system and show many advantages, such as no requirement to be connected to an electric grid [Montiel et al., 2018] and low carbon emissions [Üçtuğ and Azapagic, 2018]. The research of Pirkarami et al. illustrated the removal of organic compounds: acid orange 2, reactive blue 19 [Pirkarami et al., 2013], phenol, and aldehydes in the wastewater of a resin factory [Olya and Pirkarami, 2013] with the use of a solar PV - EC with a battery system to save $17 \%$ of the total costs.

Lithium-ion batteries are an accessible technology with benefits over metal-acid ones, such as improved lifespan, faster charge and environmental friendliness [Üçtuğ and Azapagic, 2018]. Liang et al. compared the global warming potential (GWP) of lithium-ion and GWP of nickel metal hydride batteries and illustrated that the lithium batteries generated ten times less $\mathrm{CO}_{2}$

Table 4. Optimum experimental conditions of PV-EC process variables for maximum copper removal and the lowest energy consumption.

\begin{tabular}{|c|c|}
\hline Parameter & Optimum value \\
\hline Current density $\left(\mathrm{Am}^{-2}\right)$ & 4 \\
\hline Electrolyte concentration $(\mathrm{g} / \mathrm{L})$ & 1.862 \\
\hline Application time $(\mathrm{min})$ & 10 \\
\hline
\end{tabular}

Table 5. Predicted and experimental levels for the responses at optimum operating conditions.

\begin{tabular}{|c|c|c|}
\hline Type of value & $\begin{array}{c}\text { Copper } \\
\text { reduction, } \%\end{array}$ & $\begin{array}{c}\text { Energy consumption, } \\
\mathrm{kWh} / \mathrm{m}^{3}\end{array}$ \\
\hline Predicted & 98.72 & 1.039 \\
\hline Experimental & 99.01 & 1.3 \\
\hline
\end{tabular}

Table 6. Elemental composition of sludge from the EC process based on weight (\%).

\begin{tabular}{|c|c|}
\hline Elements & Weight (\%) \\
\hline $\mathrm{C}$ & 0.7 \\
\hline $\mathrm{O}$ & 21.21 \\
\hline $\mathrm{Al}$ & 27.44 \\
\hline $\mathrm{Na}$ & 13.69 \\
\hline $\mathrm{S}$ & 2.86 \\
\hline $\mathrm{Cl}$ & 18.25 \\
\hline $\mathrm{Cu}$ & 15.85 \\
\hline Total & 100 \\
\hline
\end{tabular}




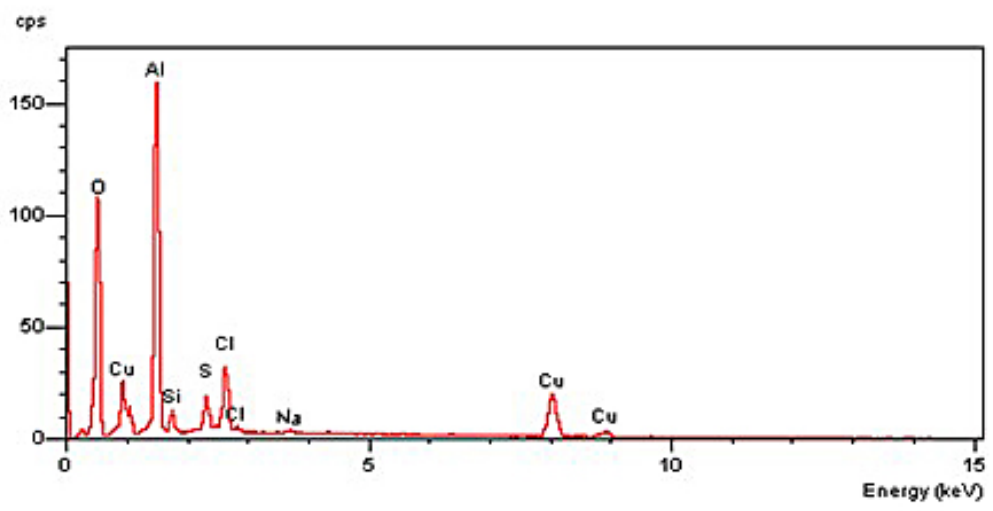

Figure 5. EDX images of sludge generated during the PV-EC process.

than the nickel metal battery (12.7 vs $124 \mathrm{~kg} \mathrm{CO}_{2}$ eq., respectively) [Liang et al., 2017]. The report concluded that lithium batteries were eco-friendly with lower $\mathrm{CO}_{2}$ emissions, no pollution with metals and greater sustainability than other batteries such as lead acid, nickel cadmium batteries.

\section{CONCLUSIONS}

Solar PV-lithium battery powered electrocoagulation system has been successfully applied for the copper reduction in aqueous solutions:

1. BBD was a reasonable method to optimize the operating status of PV-EC for a decrease of ion $\mathrm{Cu}^{2+}$. Evaluation of the variance described a high coefficient of dedication value $\left(\mathrm{R}^{2}=\right.$ 0.9977). The optimal conditions for the highest copper removal with the least amount of electric consumption were determined to be as follows: $4 \mathrm{~A} / \mathrm{m}^{2}$ current density, $1.8 \mathrm{~g} / \mathrm{L}$ electrolyte $(\mathrm{NaCl})$ concentration during 10 minutes.

2. The sludge formed after the EC process is nonhazardous and displayed excellent dewatering characteristics. Hence, the management and stabilizing of the sludge are easy and simple.

3. The developed solar PV-lithium battery device arrangement is beneficial for the reduction of copper ion and it is also cost-effective and eco-friendly.

\section{Acknowledgements}

The authors thank the Environmental Engineering Laboratory and the Advanced Technology \& Techniques at Thuyloi University for providing experimental facilities.

\section{REFERENCES}

1. Al-Saydeh S.A., El-Naas M.H., Zaidi S.J. 2017. Copper removal from industrial wastewater: A comprehensive review. J. Ind. Eng. Chem, 56, 35-44. https://doi.org/10.1016/j.jiec.2017.07.026.

2. Balintova M., Holub M., Singovszka E. 2012. Study of iron, copper and zinc removal from acidic solutions by sorption. Chem. Eng. Trans, 28, 175-180.

3. Cucchiella F., D'Adamo I., Gastaldi M. 2016. Photovoltaic energy systems with battery storage for residential areas: an economic analysis. J. Clean. Prod, 131, 460-474. https://doi.org/10.1016/j. jclepro.2016.04.157.

4. Demcak S., Balintova M., Hurakova M., FrontasyevaM. V.,Zinicovscaia I., Yushin N. 2017. Utilization of poplar wood sawdust for heavy metals removal from model solutions. Nov. Biotechnol. Chim, 16, 26-31. https://doi.org/10.1515/nbec-2017-0004.

5. Dermentzis K.K., Christoforidis A., Valsamidou E. 2011. Removal of nickel, copper, zinc and chromium from synthetic and industrial wastewater by electrocoagulation. Int. J. Environ. Sci, 1, 697-710. https://doi.org/10.6088/ijessi.00105020001.

6. Edebali S., Pehlivan E., 2016. Evaluation of chelate and cation exchange resins to remove copper ions. Powder Technol, 301, 520-525. https://doi. org/10.1016/j.powtec.2016.06.011.

7. El-Ashtoukhy E.-S.Z., Abdel-Aziz M.H. 2013. Removal of copper from aqueous solutions by cementation in a bubble column reactor fitted with horizontal screens. Int. J. Miner. Process, 121, 65-69. https://doi.org/10.1016/j.minpro.2013.03.001.

8. Ganiyu S.O., Brito L.R.D., De Araújo Costa E.C.T., Dos Santos E. V., Martínez-Huitle C.A. 2019. Solar photovoltaic-battery system as a green energy for driven electrochemical wastewater treatment technologies: Application to elimination of Brilliant Blue FCF dye solution. J. Environ. Chem. Eng, 7, 1-9. https://doi.org/10.1016/j.jece.2019.102924. 
9. Gunatilake S.K., 2015. Methods of removing heavy metals from industrial wastewater. Multidiscip. Eng. Science Stud, 1, 12-18. https://doi. org/10.13140/RG.2.1.3751.1848.

10. Hossain M.A., 2012. Removal of copper from water by adsorption onto banana peel as bioadsorbent. Int. J. Geomate, 2, 227-234. https://doi.org/10.21660/2012.4.3c.

11. Hussin F., Abnisa F., Issabayeva G., Aroua M.K. 2017. Removal of lead by solar-photovoltaic electrocoagulation using novel perforated zinc electrode. J. Clean. Prod, 147, 206-216. https://doi. org/10.1016/j.jclepro.2017.01.096.

12. Kabuk H.A., Ilhan F., Avsar Y., Kurt U., Apaydin O., Gonullu M.T. 2014. Investigation of leachate treatment with electrocoagulation and optimization by response surface methodology. Clean-Soil Air Water, 42(5), 571-577 https://doi.org/DOI 10.1002/clen.201300086

13. Kamaraj R., Ganesan P., Lakshmi J., Vasudevan S. 2013. Removal of copper from water by electrocoagulation process-effect of alternating current (AC) and direct current (DC). Environ. Sci. Pollut. Res, 20(1), 399-412 https://doi.org/10.1007/ s11356-012-0855-7.

14. Kanakaraju D., Ravichandar S., Lim Y.C. 2017. Combined effects of adsorption and photocatalysis by hybrid $\mathrm{TiO} 2 / \mathrm{ZnO}$-calcium alginate beads for the removal of copper. J. Environ. Sci, 55, 214 223. https://doi.org/10.1016/j.jes.2016.05.043.

15. Khemila B., Merzouk B., Chouder A., Zidelkhir R., Leclerc J.P., Lapicque F. 2018. Removal of a textile dye using photovoltaic electrocoagulation. Sustain. Chem. Pharm, 7, 27-35. https://doi.org/10.1016/j. scp.2017.11.004.

16. Liang Y., Su J., Xi B., Yu Y., Ji D., Sun Y., Cui C., Zhu J. 2017. Life cycle assessment of lithiumion batteries for greenhouse gas emissions. Resour. Conserv. Recycl, 117, 285-293. https://doi. org/10.1016/j.resconrec.2016.08.028.

17. Millán M., Rodrigo M.A., Fernández-Marchante C.M., Díaz-Abad S., Peláez M.C., Cañizares P., Lobato J. 2018. Towards the sustainable powering of the electrocoagulation of wastewater through the use of solar-vanadium redox flow battery: A first approach. Electrochim. Acta ,270, 17-21. https://doi.org/10.1016/j.electacta.2018.03.055.

18. Montiel V., Valero D., Gallud F., García-García V., Expósito E., Iniesta J. 2018. Prospective applications of renewable energy-based electrochemical systems in wastewater treatment. Elsevier Inc., London.

19. Nawarkar C.J., Salkar V.D. 2019. Solar powered electrocoagulation system for municipal wastewater treatment. Fuel, 270, 222-226. https://doi. org/10.1016/j.fuel.2018.09.140.

20. Ölmez T., 2009. The optimization of Cr(VI) reduction and removal by electrocoagulation using response surface methodology. J. Hazard. Mater, 162(2-3), 1371-1378. https://doi.org/10.1016/j. jhazmat.2008.06.017.

21. Olya M.E., Pirkarami A. 2013. Electrocoagulation for the removal of phenol and aldehyde contaminants from resin effluent. Water Sci. Technol, 68, 1940-1949. https://doi.org/10.2166/wst.2013.439.

22. Parlak E., Arar Ö. 2018. Removal of copper (Cu2+) from water by sulfonated cellulose. J. Dispers. Sci. Technol, 39(10), 1403-1408. https://doi.org/10.10 80/01932691.2017.1405818.

23. Pirkarami A., Olya M.E., Tabibian S. 2013. Treatment of colored and real industrial effluents through electrocoagulation using solar energy. J. Environ. Sci. Heal. - Part A Toxic/Hazardous Subst. Environ. Eng, 48, 1243-1252. https://doi.org/10.1080/ 10934529.2013.776890.

24. Shrivastava A.K., 2009. A review on copper pollution and its removal from water bodies by pollution control technologies. Indian J. Environ. Prot. 29(6), 552-560.

25. Simsek I., Karatas M., Basturk E. 2013. Cu(II) removal from aqueous solution by ureolytic mixed culture (UMC). Colloids Surfaces B Biointerfaces, 102, 479-483. https://doi.org/10.1016/j.colsurfb.2012.09.027.

26. Üçtuğ F.G., Azapagic A. 2018. Environmental impacts of small-scale hybrid energy systems: Coupling solar photovoltaics and lithium-ion batteries. Sci. Total Environ, 643, 1579-1589. https://doi. org/10.1016/j.scitotenv.2018.06.290.

27. Vasudevan S., Jayaraj J., Lakshmi J., Sozhan G. 2009. Removal of iron from drinking water by electrocoagulation: Adsorption and kinetics studies. Korean J. Chem. Eng, 26(4), 1058-1064. https://doi.org/10.1007/s11814-009-0176-9.

28. Vasudevan S., 2012. Effects of alternating current (AC) and direct current (DC) in electrocoagulation process for the removal of iron from water. Can. J. Chem. Eng, 90(5), 1160-1169. https://doi. org/10.1002/cjce.20625. 